\title{
Study of Entrepreneurship and Its Influence on the Start-Up Businesses among Students at Takoradi Polytechnic
}

\author{
Irene Darkwa \\ Department of Hospitality Management, Takoradi Polytechnic \\ P.O.Box 256, Takoradi, Ghana \\ Tel: 233-541-013-708Ｅ-mail: reney2013@gmail.com \\ Kwabena Nduro (Corresponding author) \\ Department of Graphic Design, Takoradi Polytechnic \\ P.O.Box 256, Takoradi Ghana \\ Tel: 233-243-566-169Ｅ-mail: highpriest31@ gmail.com
}

Received: July 7, 2016

doi:10.5296/gjes.v2i2.9875
Accepted: August 3, $2016 \quad$ Published: August 12, 2016

URL: http://dx.doi.org/10.5296/gjes.v2i2.9875

\begin{abstract}
Over the last decade the concept of entrepreneurship has emerged as one of the tools for development, wealth creation and economic growth. It has gradually taken its place in academia, and fast becoming a way of reducing the unemployment situation bedevilling developing countries. The current paper examined the study of entrepreneurship and its influence on the start-up businesses among students at Takoradi Polytechnic. The study employed the quantitative and qualitative methods to execute the study. The results of the study revealed that Polytechnic students have a high potential of becoming their own bosses after graduation, have knowledge of supporting institutions that exist in helping new and existing entrepreneurs, but were not aware of the assistance they offer such target groups. The study discovered a high relationship between entrepreneurship and education; students were enthused about investing in less capital intensive ventures, and also reckoned that lack of funding was not tolerated at starting-up.
\end{abstract}

Keywords: Entrepreneurship, Takoradi Polytechnic, Barriers in entrepreneurship, Entrepreneurial knowledge, Intention 


\section{Introduction}

Currently, in the world over there is a heightened interest in entrepreneurship, self-development and employment. Aghion and Howitt (1997) revisiting the Schumpeterian approach to entrepreneurship posited that innovation driven policies and activities is very critical and relevant to national development and economic growth. Schumpeter (1949) in a brief description of who an entrepreneur is, indicated that he or she has the power to hire and fire at the same time in the bid to develop his or her business. Per the description Lazear (2009) asserted that with this attribute it makes the "Entrepreneur a very crucial player in today's economy". In consonance with the above idea, Rushing (1990) pointed out that in the last decade, the study of entrepreneurship has gained much prominence, and a formidable place in the heart of higher education (college and university level).

This is evident in the functional role of higher education, of churning out well groomed and innovative graduates, with the object of championing self-employment, development and creation of jobs as an alternative to white collar jobs (Nabi \& Holden, 2008). Shinnar, Pruett and Ioney (2009) giving more insights into the issue, sought to create the impression that, educationalists of today have realised that the need to groom graduates for the ever changing market by taking the study of entrepreneurship and small business education beyond the borders of the business school of the various Higher Educational Institutions(HEIs).

In Ghana, the championing of the study of entrepreneurship and small business management was initiated by successive governments over the years with the object of discouraging the notion held by graduates that one can only make it, when one finds itself in the public sector, and as well reduce unemployment. The Provisional National Defense Council (PNDC) government initiated the Venture Capital Trust Fund (VCTF); to provide low asset financing to small businesses to ensure they grow, create wealth and jobs for the private sector; National Board for Small Scale Industries (NBSSI) was also set up to undertake six main functions; define and establish what constitutes small scale industry in Ghana, organise a field of extension network for the identification of projects, data collection and dissemination of information and provision of feedback; promote entrepreneurship programs and activities for the development of new and existing businesses; encourage the formation of co-operatives, the building of individual estates and other infrastructure for the small scale industry development; define the roles and responsibilities of the implementation of special programmes in the areas of finance, technology, and management; and implement all polices in relation to small scale industries as approved by government and seeing to it that the infrastructural need by the small scale industry development is well established (Boachie-Mensah \& Boahene, 2013).

Besides this, the NBSSI revolving fund scheme was set up to benefit both new and existing businesses, and targeted enterprises in the manufacturing and service sectors of the economy. The next major initiative was the Business Assistance Fund (BAF) which was introduced to restore the production of capacity of enterprises and industries of proven potential, the Programme of Action to Mitigate the Social Cost of Adjustment (PAMSCAD) was established to relieve the adverse effect of the Economic Recovery Programme (ERP) and the 
Structural Adjustment Program (SAP), provide employment generation projects, alongside credit facilities for small scale enterprises. The program had its target being redundant workers and the unemployed who were in need of credit and soft loans for establishing themselves.

Aside these establishments, other schemes and programmes were also mounted to assist financing small scale enterprises. According to Boachie-Mensah and Boahene (2013) set ups like the Export Development and Investment Fund (EDIF), operational under Exim Guaranty Company Scheme of the Bank of Ghana, was introduced to assist in industrial and export services, and also charged with the responsibility of developing the industrial sector, Ghana Regional Appropriate Technology Industrial Service (GRATIS) which had branches in all the ten regions was to provide technical and managerial support through the training to small and medium scale enterprises, the Ghana Enterprise Development Commission(GEDC) had the mandate to create the platform and enabling environment for local businessmen to penetrate the fields where only foreigners operate.

The erstwhile Kufour government in support of the development for small and medium scale enterprises, established the National Youth Employment Programme (NYEP) to offer Ghanaian youth the platform to find themselves in meaningful and decent job employment, after the exit of the government the programme metamorphosed into Ghanaian Youth Employment and Entrepreneurial Development Agency (GYEEDA) alongside Youth Enterprise Support (YES) is a secretariat established in all the ten regions of Ghana with the object of supporting Ghanaian youth in three core areas thus; Youth Employment \& Entrepreneurial Development; Youth Policy \& governance, and youth Participation \& Active Citizenship, and Local Enterprises and Skills Development Programme (LESDEP) a public private partnership under the auspices of the ministry of local government and rural development that seeks to; create and facilitate the acquisition of technical entrepreneurial and other specialized skills that lead to the creation and management of sustainable businesses by the unemployed youth in Ghana; provide start up equipment and post set- up support services (Asiedu \& Nduro, 2015).

Higher educational institutions in Ghana, in the bid to support government's initiative and vision incorporated the study of entrepreneurship and small business management in their educational curricula in response to the clarion call for products with skills and the spirit for initiating excellent ideas and become their own bosses; and secondly as a proactive approach in solving or reducing graduate unemployment believed to be on the ascendency. In Takoradi Polytechnic the study of entrepreneurship is mandatory for all and sundry to acquire the required skills, knowledge and the capacity to be on their own after school. It is read mostly in the year two and three.

\subsection{Problem Definition}

Van Der Walt and Van Der Walt (2008) indicated that establishing one's own business or entrepreneurship is the solution to the increasing trend of unemployment among graduates, but unfortunately it is the unfavoured option and in most cases the last option they resort to. According to Massad and Tucker (2009), the issue of inculcating the entrepreneurial spirit 
into graduates has been ignored. This they largely attributed to the conception that, one can only make it in life, when you secure employment with the public sector and as such does not look promising for the future. On their part Ebewo and Shambare (2012); Makgasa and Ognori (2012) noted most fresh graduates prefer receiving guaranteed income of formal employment as against the risk associated with starting one's own business. They also pointed out the manner in which students are taught entrepreneurship in school makes it unattractive to delve into after school. Approximately, every year over 2000 polytechnic students graduate in Ghana, all with the hope of finding a job in the public or private sectors. Looking at these huge numbers, majority find themselves eventually unemployed and sadly not opting for self- employment. Despite taking a course in entrepreneurship still most will prefer not to become entrepreneurs (Adjei et al., 2014). It is in this light that the researcher would like to investigate the study of entrepreneurship and its influence on the start-up of businesses among students at Takoradi Polytechnic.

\subsubsection{Purpose of the Study}

The purpose of the study is to investigate the study of entrepreneurship and its influence on the start-up businesses among students at Takoradi Polytechnic.

\subsubsection{Research Objectives}

i. To find out the student's level of entrepreneurial knowledge;

ii. To ascertain whether students have the intention to set up their own business;

iii. To ascertain whether there is a relationship between entrepreneurial education and intention to start- up business;

iv. To analyse the perceived barriers that graduates are likely to encounter in a bid to start-up their own business.

\section{Literature Review}

Entrepreneurship in the view of the World Economic Forum (2009) is a force to reckon with when it comes to development, and actually have significant influence on the growth of an economy, its recovery and progress by stimulating innovation and empowering individual. In support of this, Baumol (1990) added entrepreneurship as an activity is very crucial for national development. Expatiating further and trying to figure out who an entrepreneur is, noted they are characters with unique business ideas, who can pick innovative ideas from others in the light of the existing environmental conditions with the object of initiating new ones or expanding new ones but have the will to make the ideas a reality. One should be cautious not to play the good side alone but must also emphasise that not all them become successful, as some fail in the process. Aghion and Howitt (1997) added entrepreneurs are agents of development, and to a larger extent employer of labour when he or she decides to grow his/her firm. This assertion prompted Lazear (2003, p. 23) to declare that "the entrepreneur is the single most important player in a modern economy".

Empirical evidence from literature on theme shows rich findings and related works to the 
current study. Hossan (2013) in a study on United Arab Emirates (UAE) business students entrepreneurial knowledge, preferences and perceived barriers discovered that most of the respondents were between the age group of 21-25 years of age, meaning they fall within the economically active group serving as a very good platform, and opportunity for awareness creation, sensitization and inculcating the spirit of enterprise building into them. They also found out that majority of the participants were working and still doing so before enrolling in the university. It can be inferred that for most United Arab Emirates (UAE) students they work whilst studying. Almost half of the respondents overwhelmingly declared knowing an entrepreneur in person.

In relation to the students' knowledge of venture support entities, Hossan et al. (2013) revealed was very high among participants, but on the contrary they were at sea as to the opportunities and technical assistance they can lend to existing and new entrepreneurs. It was observed that UAE business students do not love to engage in capital intensive ventures, no reason was assigned but probably due to the expensive and complex nature they present. Enquiring on the business choice of respondents, there was quite a significant difference on gender basis. Moving into specifics, restaurant business seem to favour both gender, however, business like construction and real estate development were tolerated by male participants. In a sharp contrast and very obvious, their female counterparts overwhelmingly favoured retailing. The above deliberations highlight key indicators which will be crucial for small scale enterprises policies and programmes.

Another revelation from the study that was good for up and coming entrepreneurs and should be encouraged was that UAE business students believe in partnership business compared to the traditional sole proprietorship. At the gender level, the male students were private limited business oriented, with their female counterparts settling for partnership form of business. Government should take into consideration the dichotomy and formulate policies and programmes which will take care of the inequities and disparities against women when it comes to business initiatives and start-up.

\subsection{Entrepreneurship and Education}

Ulrich (2006) discussing the relationship between entrepreneurship and education posited that the drive to engage in business and the will power to become an entrepreneur is linked to the level of awareness about knowledge of familiarity with the concept of entrepreneurship as being a viable career path. Among other social institutions, education has probably the most important impact on raising awareness and attractiveness to the characteristics and attributes of entrepreneurship. He further explained education as a tool that arms young graduates to the teeth in terms of understanding, and the necessary skills needed for entrepreneurship.

Similarly, Deary Report (1997), also suggested that entrepreneurship education is crucial in assisting young people to develop entrepreneurial skills, attributes and behaviours as well as develop enterprise awareness, to understand and to realise entrepreneurship as a career option. The report was also quick to add that entrepreneurship is not the only means to enhance youth entrepreneurship and self- employment, but at the same time a platform to equip young people and graduates with the required attitudes (personal responsibility) and skills 
(flexibility and creativity) necessary to cope with the uncertain employment paths of today's societies.

This implies young people and graduates cannot still hold onto the traditional "job-for-life" careers, but rather portfolio careers (contract employment, freelancing, period of self -employment). This makes enterprise education a worthwhile and relevant preparation grounds for the job market, and the economy in which eventually graduates will operate. The deliberations so far show a positive correlation between education and students establishing their own businesses. It also helps students to self-assess themselves, and their attitude towards entrepreneurship, as well as general occupation aspirations and achievement (Ulrich, 2006).

Charney and Libecap (2000), in a comparative analysis of business school graduates of Berger Entrepreneurship Programme in the United States with other graduates, discovered entrepreneurship education enhances risk taking in the formation of new ventures, and the extent of been self-employed. They also sought to create the impression that entrepreneurship graduates have higher incomes, higher assets and indirectly higher job satisfaction compared to other business graduates. They also suggested that entrepreneurship education contributes to the growth of small firms that employ the services of entrepreneurship graduates, and firms owned by entrepreneurship graduates tend to be larger and have more sales than those owned by non- entrepreneurship graduates. In conclusion the two writers affirmed that entrepreneurship education promotes technology based firms and products.

Gallaway (2005) touched on the impact and potential of entrepreneurship in higher education noted that students who have completed an entrepreneurship module or course at the University or Polytechnic level are more likely to aim for entrepreneurship within their careers than students who have not included enterprise study in their educational career. In the same vein, enterprise education has a positive effect on the potential quality of entrepreneurs and that currently, is most marked in these disciplines, in which students are less likely to be aware of the possibility of entrepreneurship as a career choice when they are not exposed directly to the suggestion via enterprise education.

Basu and Virick (2008) posited that education and prior experience have a positive correlation with entrepreneurial behaviour. Van der Walt and Van der Walt (2008) cautioned that there may be a positive correlation alright thus, between higher education and intention to engage in entrepreneurship, but having a tertiary education and training does not automatically make you one. Talas, Celik, and Oral (2013) citing the Global Entrepreneurship Monitor Turkey Report (2011) sought to create the impression that people who have undergone higher education are opportunity driven and have multiple options to employment and business prospects available to him. It must be put on record that, entrepreneurship education has been employed as one of the major tools to influence and increase the entrepreneur attitudes of would be business starters, but was smart to emphasise that, the indicators of the decision to start-up a business venture was not clear enough. Joining the discourse Pajarner et al. (2006) concluded that educated and well groomed entrepreneurs are seen as more innovative, have the ability to employ current and innovative business models, 
with emphasis on technology as the bedrock of the venture.

In an attempt to discover the relationship between entrepreneurship education and being self-employed, Clarke et al. (1984) noted that entrepreneurship courses have a strong potential to influence venture creation. This is evident in a study by Davidson and Hony (2003) considering the activities of nascent entrepreneurs (individual with serious efforts to set up a business) discovered that the propensity to start up is high compared to people or individuals who have actually participated in a workshop educating participants on how to start. Mc Mullard and Guillar (1998) evaluating a graduate degree programme in entrepreneurship in an Australian university revealed that $87 \%$ of the graduates established their own ventures exactly two years after graduation.

Kolvereid and Moen (1997) in the study found out that Norwegian students who had taken a course in entrepreneurship had a much higher potential or propensity to become their own bosses after school than students who have not. Muthalib and Yulianti (2015) following keenly graduates of an engineering programme at a Canadian university also established that students who read entrepreneurship courses elective in school were more likely to be business owners than those who have not. All the discourse so far points to one thing that there is a strong and positive relationship between the study of entrepreneurship, intention to start-up and employment

\subsection{Perceived Barriers}

On the perceived barriers to start up business Adjei, Pinkrah and Denanyoh (2014) found out that lack of entrepreneurial support, inappropriate teaching methods, lack of exposure and poor course content were the mitigating factors against starting up business by graduates. Giacomin, Pruett, Shinnar, Llopis, and Toney (2010), identified financial, knowledge and lack of experience as barriers to start up business among Indian students compared to their Chinese, Spanish and Belgian compatriots. Similarly, Robertson (2004) pointed out lack of ideas an impediment to start up. Wong and Choo (2006) believes individuals who want to become entrepreneurs are motivated by both intrinsic and extrinsic rewards, but the barriers on the other hand they noted are lack of capital, skills, confidence and compliant cost, similarly Schoof (2006), exhibited social/cultural attitudes, entrepreneurial education, access to finance/start up financing, Administrative/regulatory framework and business support services as notable barriers.

Hossan, Parankandi, and Saber (2012) observed that mean figures for female students were higher for all the barriers an indication that female students face a strong challenge of starting up business compared to their male counterparts. This indicates that men have the heart for business establishment, notwithstanding the risks and unforeseen circumstances surrounding it but both were quick to reckon that lack of experience, knowledge and skills were the most intimidating factors in becoming one's own bosses. The usual known factors; lack of funding and government support are no longer tolerated as barriers.

Tanveer, Gilliani, Rizvi, and Latif (2010) examining barriers to start-up business in Pakistan discovered respondents attested to the fact that all listed barriers were strong factors 
militating against start-up business, but weak economic environment was seen as the major factor restraining one from becoming his or her own boss. The uncertainty about the future was also paramount. The next set of factors were financial resources comprising bank finance, lack of assets and lack of savings. Lack of expertise and skills, and lack of support from friends and family and, government were not ruled out. In general lack of skill, lack of assistance, lack of family and friends support, and fear of uncertainty were not tolerated at all.

Touching on the intention to start business Adjei et al. (2014) discovered that $65.3 \%$ of the respondents had thought of becoming their own bosses, while $23.1 \%$ expressed fear of taking the initiative probably with the object of not losing their entire investment, and $8.8 \%$ had never dreamt of establishing their own business, if not exaggerating may conclude that they are the category who have vowed to seek white collar jobs.

\section{Methodology}

\subsection{Research Approach}

Research approach is the step aimed at designing the research study in such a way that the essential data can be gathered and analysed to arrive at a solution (Sekaran, 2003). The current paper employed both the quantitative and qualitative designs. The quantitative method uses objective measurement and statistical analysis of numeric data to understand and explain a phenomenon. In the paper it was used to generate percentages, mean ratings and standard deviation figures for data collected. Qualitative approach in contrast focused on understanding tendencies from the human perspective, and in course of the study (Kumar, 2005), it was employed in the analysis and discussion to describe, explain and make inferences of the variables studied. The rationale for using the two methods at the same time was that, the two can be used to execute any research activity notwithstanding the paradigm of the study.

\subsection{Study Population}

The population of the study comprised the Higher National Diploma (HND) students of Takoradi polytechnic. The target population was the HND 1-3 students who were and had read entrepreneurship in the course of their programme of study. The students were mainly full time and evening school students. The units for the target population were picked from the following departments within the institution; Graphic Arts, Hospitality Management, Fashion Design and Technology, Furniture Design and Interior Decoration, Sculpture Design, Purchasing and Supply, Accountancy, and Marketing.

\subsection{Sample}

Respondents were selected to participate in the study by employing the purposive and convenience non-probability sampling techniques. Purposive sampling is used to select participants from the population who have good prospects for accurate information, and in the study it was employed to select related departments who offer entrepreneurship as a course to their students. Alongside this technique was the convenience sampling technique. According to Bhattacherjee (2012) convenience sample is a technique employed to select 
participants from the population that is close to hand, readily available, or convenient for the study hence, the researcher administering the questionnaire to students who happened to be available at the time of conducting the study.

\subsection{Instrument Development}

A self-administered questionnaire was designed to solicit information from participants for reliability sake. Due to the ethics and regulations governing research, participation in the study was purely voluntary. The questionnaire was administered during the week prior to the end of semester examination. A total of 120 questionnaires were distributed, 83 were returned and usable. The questionnaire had five sections; A: picked data concerning the demography of respondents, B: discussed the relationship between Education and Entrepreneurship, C: touched on Entrepreneurial Knowledge and Support Services, D: Entrepreneurial Preferences (forms and nature of business) and; E: Perceived Barriers to Entrepreneurship. Data was analysed using SPSS and to enhance understanding employed tables, graphs, means and standard deviation ratings to enable the authors draw valid conclusions from the analysis.

\section{Results and Discussion}

Table 1. Demographic Features

\begin{tabular}{|l|c|c|c|}
\hline Characteristics & N & Frequency & Percentage \\
\hline Gender & $\mathbf{8 3}$ & & \\
\hline Male & & 48 & 57.8 \\
\hline Female & & 35 & 42.2 \\
\hline Age & & & \\
\hline $16-20$ & & 40 & 10.8 \\
\hline $21-25$ & & 23 & 48.2 \\
\hline $26-30$ & & 11 & 27.7 \\
\hline Above 30 & $\mathbf{8 3}$ & & 13.3 \\
\hline HND & & 17 & 20.5 \\
\hline I & & 22 & 26.5 \\
\hline II & & 44 & 53.0 \\
\hline III & $\mathbf{8 3}$ & & 33.7 \\
\hline School & & 28 & 19.3 \\
\hline Business & & 16 & 33.7 \\
\hline Engineering & & 28 & 13.3 \\
\hline Applied Arts & & 11 & 37.3 \\
\hline Applied Science & $\mathbf{8 3}$ & & 26.5 \\
\hline Work Experience & & 31 & 16.9 \\
\hline 1-3years & & 22 & 19.3 \\
\hline 4-6years & & 14 & \\
\hline 6years & & 16 & \\
\hline Self- employed experience & & & \\
\hline
\end{tabular}

Source: Field Survey, June 2015. 


\subsection{Demography}

Table 1 exhibiting the demographic information of the respondents, out of the total 83 respondents $58 \%$ were males and $42 \%$ female students. This has been the trend over the years which indicate that more males are admitted into the Polytechnic. It could also be that in terms of performance, males excel more than their females at the high school level, another school of thought also believe that, due to the technical nature of the courses offered at the Polytechnic there are more male applicants hence their number. In terms of age $48.2 \%$ of the respondents were in the age group between $21-25$ years and $11 \%$ of the respondents were below 20 years of age. But it must be highlighted that $89.2 \%$ of the respondents were within the economically active group. With respect to the level of study a heavy majority of $79 \%$ were in year 2 and 3, an indication of having a rich source of information for making valid conclusions. Evidence from the survey in relation to the programme of study saw the school of business studies and applied arts having $67.4 \%$ of the respondents come from their end, for the authors it was good in that, their programme of study is such that after completion they are to set up their own establishments and employ others to work for them. In terms of work experience table 4.1 shows that almost all the respondents have had some amount of work experience before enrolling for the HND programme. Nearly $37.3 \%$ of the respondents had work experience between 1-3 years, $27 \%$ have 4-6years of work experience. Only 17\% had worked for 6 years, $19 \%$ were their own bosses.

\subsection{Entrepreneurial Knowledge and Support Services}

\subsubsection{Intention to Start-Up}

Table 2. Intent of establishing one's own business

\begin{tabular}{|l|c|c|c|}
\hline \multirow{2}{*}{ Intent } & \multicolumn{2}{|c|}{ Gender of Respondents } & \multirow{2}{*}{ Total } \\
\cline { 2 - 3 } & Male & Female & \\
\hline Thought of & 38 & 31 & 69 \\
\hline Scared of doing so & 5 & 2 & 7 \\
\hline Have no intention & 5 & 2 & 7 \\
\hline Total & $\mathbf{4 8}$ & $\mathbf{3 5}$ & $\mathbf{8 3}$ \\
\hline
\end{tabular}

Source: Field Survey, June 2015.

When respondents were quizzed on their intention to start a business after graduation (also done on gender basis), $47 \%$ of the male respondents had thought of establishing their own business after school, and an equal percentage (seven percent) were scared of doing so and had no intention whatsoever of setting up a business. On the part of the female respondents $37 \%$ had thought of setting up their own business, with an equal percentage of two scared of doing so and having no intention of doing so respectively. From the trend it is obvious that the male respondents are more entrepreneurship inclined than their female counterparts. This 


\section{Macrothink}

Global Journal of Educational Studies

ISSN 2377-3936 2016, Vol. 2, No. 2

implies that students have high interest in establishing their own business.

\subsubsection{Knowledge of an Entrepreneur in Person}

The respondents were asked to indicate whether they knew personally any entrepreneur, $57 \%$ of the male respondents compared to $43 \%$ female respondents knew an entrepreneur in person. The trend shows that majority of the respondents knew an entrepreneur in person and as such their ability to describe an entrepreneur earlier in the discussion. Hossan et al. (2000) in a related study found out that nearly half of the respondents knew an entrepreneur in person.

4.2.3 Knowledge of Entrepreurial Services and Support Agencies

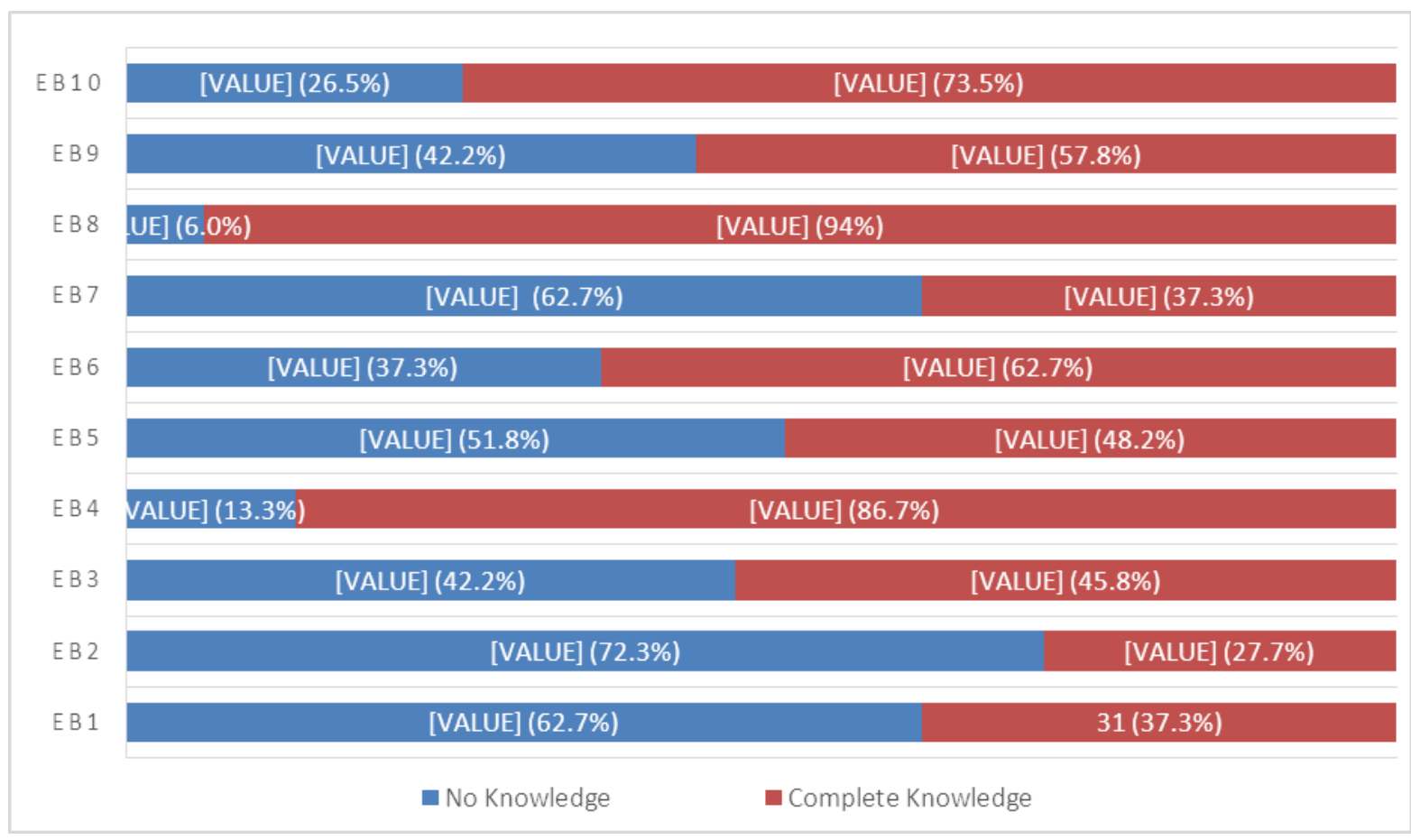

Figure 1. Entrepreneurial service and support agencies

Source: Field Survey, June 2015.

This section of the survey was meant to discover from the respondents the extent to which they were aware of the existence of these entities that offer support and services to graduates who have the will, and love to start their own business. The survey results shows respondents had an appreciable knowledge of the enumerated agencies. Ninety-four percent of them mentioned GYEEDA had complete knowledge of its existence and function, closely on its heels was loan facilities (87\%), small and medium scale enterprises association pulled $74 \%$ with business centres following suit with $63 \%$. It can be inferred from the trend that, respondents had complete knowledge of agencies and the support services they offer but the respondents seem to be less aware about the opportunities. It was refreshing to know from 
them that they were taught in the entrepreneurship class.

\subsection{Relationship between Entrepreneurship and Education}

Table 3. Impact of education on entrepreneurship

\begin{tabular}{|l|c|c|c|c|c|c|}
\hline \multirow{2}{*}{ Variables } & \multicolumn{9}{|c|}{ Percent Likert Response } & \multirow{2}{*}{ MR } & SD \\
\cline { 2 - 6 } & $\mathbf{1}$ & $\mathbf{2}$ & $\mathbf{3}$ & $\mathbf{4}$ & & \\
\hline Entrepreneurship skills, attributes and attitudes & 51 & 40 & 6 & 4 & 1.63 & 3.6 \\
\hline Enterprise awareness & 41 & 54 & 4 & 1 & 1.65 & 0.61 \\
\hline $\begin{array}{l}\text { Understand and to realize entrepreneurship as a } \\
\text { career option }\end{array}$ & 40 & 52 & 8 & 0 & 1.69 & 0.62 \\
\hline Creativity and innovation & 59 & 35 & 4 & 2 & 1.49 & 0.69 \\
\hline Enhance self- employment & 51 & 47 & 2 & 0 & 1.52 & 0.55 \\
\hline $\begin{array}{l}\text { Enhances risk-taking in the formation of new } \\
\text { ventures }\end{array}$ & 28 & 58 & 15 & 6 & 1.87 & 0.64 \\
\hline $\begin{array}{l}\text { Firm owned by entrepreneurship graduates } \\
\text { tend to be larger and have more sales than non- } \\
\text { graduate entrepreneurs }\end{array}$ & 23 & 35 & 35 & 7 & 2.27 & 0.90 \\
\hline $\begin{array}{l}\text { Entrepreneurship education help promotes } \\
\text { technology based firms and products }\end{array}$ & 39 & 52 & 6 & 4 & 1.75 & 0.73 \\
\hline Business plan & 41 & 43 & 13 & 2 & 1.74 & 1.92 \\
\hline $\begin{array}{l}\text { Mobilize resources(financial, human, material) } \\
\text { for establishing the business }\end{array}$ & 24 & 63 & 11 & 2 & 1.92 & 0.67 \\
\hline
\end{tabular}

Source: Field work June, 2015.

$\mathrm{MR}=$ Mean Response, SD $=$ Standard Deviation, 4= Disagree, 3= Strongly Disagree, 2= Agree 1= strongly agree.

Table 3 quizzed respondents as to whether undertaking entrepreneurship education will aid them to develop the enumerated skills and attitude. The results showed a trend where the responses were between the strongly agree and agree. Mobilization of resources for establishing businesses had the highest response (63\%) strongly agreed to the assertion that people who have had entrepreneurship education are able to mobilise resources for business, $24 \%$ in support of it agreed, closely on its heels was creativity and innovation (59\%) and 35\% for strongly agree and agree respectively. In the same vein enhanced risk taking in the formation of new venture recorded $58 \%$ and $28 \%$, enterprise awareness followed suit with $54 \%$ and $41 \%$, understand and to realise entrepreneurship as a career option had a close margin of $52 \%$ and $40 \%$ respectively. Lastly, one of the most tolerated item was entrepreneurship education promoting technology based firms and products (52\%) and 39\% respectively. The above trend is an indication that having education propels you to become a successful entrepreneur, hence a relationship between the two variables. This observation is 


\section{Al Macrothink}

Global Journal of Educational Studies

ISSN 2377-3936 2016, Vol. 2, No. 2

consistent with that of Ulrich (2006) who asserted that zeal to be one's own boss is linked to the familiarity with concept of entrepreneurship as viable venture; Deary Report (1997) reported it helps young people to develop entrepreneurial skills, attributes and behaviours. The report was also quick to add that entrepreneurship is not the only means to enhance entrepreneurship spirit and self-employment, but at the same time a platform to equip young people and graduates with the required attitudes (personal responsibility) and skills (flexibility and creativity) necessary to cope with the uncertain employment paths of today's societies.

\subsection{Entrepreneurial Preference}

Table 4. Form of business

\begin{tabular}{|l|c|c|c|}
\hline \multirow{2}{*}{\multicolumn{1}{|c|}{ Form of Business }} & \multicolumn{2}{c|}{ Gender of Respondents } & \multirow{2}{*}{ Total } \\
\cline { 2 - 3 } & Male & Female & \\
\hline Sole proprietorship & 25 & 27 & 52 \\
\hline Limited liability company & 10 & 3 & 13 \\
\hline Partnership & 7 & 2 & 9 \\
\hline Joint stock company & 1 & 1 & 2 \\
\hline Cooperative & 5 & 2 & 7 \\
\hline Total & $\mathbf{4 8}$ & $\mathbf{3 5}$ & $\mathbf{8 3}$ \\
\hline
\end{tabular}

Source: Field Survey, June 2015.

Most of the female respondents preferred sole proprietorship to any other form of business (32\%) against $30 \%$ of their male compatriots, looking at the margin it was a close call. On other side, the trend was dominated by the males throughout. The issue is that looking at limited liability, partnership, joint stock and cooperative it requires taking calculated risks to be able to venture, so the trend creates the impression that women or females in particular fear of taking risk. This finding was in sharp contrast with that of Hossan et al. (2000) which established that Partnership was the most preferred form of business among UAE students, but further investigation revealed in terms of gender sole proprietorship is equally preferred as form of business between male and female students.

\subsection{Barriers to Start-Up Business}


Table 5. Perceived barriers to entrepreneurship

\begin{tabular}{|l|c|c|c|c|c|c|}
\hline \multicolumn{1}{|c|}{ Factors } & \multicolumn{3}{c|}{ Percent Likert response } & \multirow{2}{*}{ MR } & SD \\
\cline { 1 - 6 } & 1 & 2 & 3 & 4 & & \\
\hline Lack of Funding & 1.2 & 3.6 & 28.9 & 66.3 & 3.12 & 1.05 \\
\hline Lack of Positive Attitude towards Entrepreneurship & 25.3 & 22.9 & 9.6 & 42.2 & 2.28 & 1.11 \\
\hline Lack of Awareness about Opportunities & 32.5 & 25.3 & 24.1 & 18.1 & 2.36 & 1.02 \\
\hline Lack of Experience & 21.7 & 38.6 & 21.7 & 18.1 & 2.39 & 1.10 \\
\hline Lack of Government Support & 26.5 & 27.7 & 26.5 & 19.3 & 2.81 & 1.19 \\
\hline Lack of Skills To Manage Firms & 21.7 & 16.9 & 20.5 & 41.0 & 2.60 & 1.07 \\
\hline Lack of Access To Information & 18.1 & 30.1 & 26.5 & 25.3 & 2.39 & 0.97 \\
\hline Fear of Failure & 36.1 & 28.9 & 21.7 & 13.3 & 2.59 & 1.06 \\
\hline Lack of Exposure & 18.1 & 30.1 & 26.5 & 25.3 & 2.39 & 0.97 \\
\hline $\begin{array}{l}\text { Lack of Information about Government Agency that } \\
\text { can Assist Funding the Business }\end{array}$ & 19.3 & 37.3 & 22.9 & 20.5 & 2.45 & 1.03 \\
\hline Inappropriate Teaching of the Course & 28.9 & 37.3 & 21.7 & 12.1 & 2.15 & 0.97 \\
\hline Lack of Savings & 34.9 & 34.9 & 15.7 & 21.1 & 2.15 & 0.97 \\
\hline Lack of Interest & 38.6 & 27.7 & 19.3 & 13.3 & 2.07 & 1.06 \\
\hline Fear of losing your investment & 21.7 & 25.3 & 24.1 & 28.9 & 2.60 & 1.13 \\
\hline Fear of unstable income & 30.1 & 26.5 & 22.9 & 20.5 & 2.34 & 1.12 \\
\hline Decreased standard of living & 26.5 & 28.9 & 19.3 & 25.3 & 2.43 & 1.14 \\
\hline
\end{tabular}

Source: Field work, June 2015.

$\mathrm{MR}=$ Mean Response, $\mathrm{SD}=$ Standard Deviation, $4=$ Extreme Barrier, $3=$ Moderate Barrier, $2=$ Somewhat A Barrier, $1=$ Not A Barrier.

This section of the study sought to find out from respondents' barriers they anticipate may hinder their intention of starting- up their own business. Respondents were given 16 perceived barriers to select from. The results of the survey proved that the following with their mean ratings or values were the critical factors that could come between the respondents and establishing their own businesses after school.

Table 6. Critical barriers selected

\begin{tabular}{|c|l|c|}
\hline Serial Number & Barrier & Mean Ratings \\
\hline 1 & Lack funding & 3.12 \\
\hline 2 & Lack of government support & 2.81 \\
\hline 3 & Lack of skills & 2.60 \\
\hline 4 & Fear of losing investment & 2.60 \\
\hline 5 & Fear of failure & 2.59 \\
\hline 6 & $\begin{array}{l}\text { Lack of information about government agencies that } \\
\text { can assist in funding }\end{array}$ & 2.45 \\
\hline 7 & Decreased standard of living & 2.43 \\
\hline
\end{tabular}

Source: Field Survey, June 2015. 
The following barriers were extracted from Table 6, and they were factors that have the high tendency of preventing fresh graduates from establishing their own business. Majority lamented on lack of funding as the first and foremost barrier, lack of government support, skills, fear of losing investment and failure. At the bottom half of the table was lack of information and surprisingly decreased standard of living.

\section{Discussion and Conclusion}

The current paper discovered that most of the respondents were between the age group of 21-25 year. This finding was consistent with that of Hossan et al. (2013), and they asserted that this age group serves as a very good platform, and opportunity for awareness creation, sensitization and inculcating the spirit of enterprise building into them and the country at large. Moreover, most of the respondents were and still working an indication of the students having some requisite experience before enrolling for their respective programmes. The blend of working age and experience on the part of the Polytechnic students is a clear indication that they had the will to start-up businesses after school. On the intent to start-up business, majority of the students declared and revealed their desire to be their own bosses after graduation, in the same vein, Adjei et al. (2014) found out that, most of the respondents were highly interested in setting up their own business after graduation. Majority of Polytechnic students had extensive knowledge of the existence of entrepreneurial service and technical agencies in Ghana, but per Hossan et al. (2013) discovery they knew little of the enormous services and technical advice the agencies could offer would be, and existing entrepreneurs and the little that were aware have also not taken the trouble to exploit it to the fullest. Results from the study stress emphatically that there is a positive correlation between education and entrepreneurship and studies by Basu and Virick (2008) gives credence to it by indicating that education and prior experience have a positive correlation with entrepreneurial behaviour. Van der Walt and Van der Walt (2008) cautioned that there may be a positive correlation alright thus, between higher education and intention to engage in entrepreneurship, but having a tertiary education and training does not automatically make you one. Talas, Celik and Oral (2013) citing the global entrepreneurship monitor turkey 2010 report (2011) sought to create the impression that people who have undergone higher education are opportunity driven and multiple options to employment and business prospects available to him. It must be put on record that, entrepreneurship education has been employed as one of the major tools to influence and increase the entrepreneur attitudes of would be business starters, but was smart to emphasise that, the indicators of the decision to start-up a business venture was not clear enough. Joining the discourse Pajarner et al. (2006) concluded that educated and well groomed entrepreneurs are seen as more innovative, have the ability to employ current and innovative business models, with emphasis on technology as the bedrock of the venture. Considering the form of business, the current paper did not discover any significant difference between the male and female students of Takoradi Polytechnic, but generally, majority of student's favoured sole proprietorship compared to others. Pitting this results against that of Hossan et al. (2013), you realise a sharp contrast as UAE students favoured partnership. This shows that graduates from Takoradi Polytechnic did not have the knack for investing in capital intensive ventures rather less investment ventures as a result of 


\section{Al Macrothink}

Global Journal of Educational Studies

ISSN 2377-3936

2016, Vol. 2, No. 2

the fear of losing their entire investment when the business environment becomes tough. It could also be that due to the complex nature and the legalities involved in forming the others, would prefer sole proprietorship. This should serve as an indicator for government in its policies and programmes towards small scale enterprises and the direction to channel more resources when it comes to establishing new business ventures, and the existing ones for expansion. The study found out that Polytechnic students were very nervous of the enumerated challenges to start-up. They did not tolerate lack of funding, government support, skills, information, fear of losing investment and failure and lastly decreased standard of living.

\section{Recommendations}

The polytechnic should endeavor to establish Entrepreneurship and Small Business Centre which will be responsible for liaising with business and organizations to invite prominent and established enterprise figures to interact with students, and offer practical enterprise courses for them as well.

Periodical business plan competitions should organised by the institutions and well sponsored by organisations to adopt the most promising plan for implementation, and well monitored to develop and grow.

The campaign for facilitating the awareness of the various venture support agencies and technical organisations should be intensified to broadcast the opportunities and support available at these places to be offered to would be entrepreneurs and existing ones for assessing them.

\subsection{Limitations}

Due to the size of the sample and the fact that not all the programmes in the polytechnic offer entrepreneurship as a course to their students, generalizing the findings to all and similar situations will not be appropriate.

As a result of the examination period in which questionnaires were administered, it's believed that respondents may not have taken their time to answer the questions which in a way may affect the results

\subsection{Suggestions for Further Research}

For future studies, the authors expect to focus in-depth on various institutional supports and technical agencies available in Ghana for establishing new business ventures and expanding existing ones.

\section{References}

Adjei, K., Pinkrah, B. S., \& Denanyoh, R. (2014). Barriers to entrepreneurship among business students in Sunyani Polytechnic of Ghana. International Journal of Innovative Research \& Development, 3(4), 30-36.

Aghion, P., Harris, C., \& Vickers, J. (1997). Competition and growth with step-by-step 
innovation: An example. European Economic Review, 41, 771-782. http://dx.doi.org/10.1016/S0014-2921(97)00036-6

Anol, B. (2012). Social science research: Principles, methods and practices. University of Florida, U.S.A.

Asiedu, M., \& Nduro, K. (2015) Polytechnic Students' Entrepreneurial Knowledge, Preferences and Perceived Barriers to Start - Up Business. European Journal of Business and Management, 7(21), 20-28.

Basu, A., \& Virick, M. (2008). Assessing Entrepreneurial Intentions amongst Students: A Comparative Study. Peer Reviewed Paper, San Jose State University.

Baumol, W. (1990). Entrepreneurship in Economic Theory. American Economic Review, Papers and Proceedings, 58(2), 64-71.

Boachie-Mensah, F. O., \& Boahene, R. (2013). Entrepreneurship. University of Cape Coast: Cape Coast.

Charney, A., \& Libecap, G. D. (2000). The impact of entrepreneurship education: An evaluation of the Berger Entrepreneurship Program at the University of Arizona, 1985-1999. Report to the Kauffman Centre of Entrepreneurial Leadership, Kansas City, Missouri. http://dx.doi.org/10.2139/ssrn.1262343

Clark, B. W., Davis, C. H., \& Harnish, V. C. (1984). Do courses in entrepreneurship aid in new venture creation? Journal of Small Business Management, 22(2), 26-31.

Davidsson, P., \& Honig, B. (2003). The role of social and human capital among nascent entrepreneurs. Journal of Business Venturing, 18(3), 301-331. http://dx.doi.org/10.1016/S0883-9026(02)00097-6

Dearing Report. (1997). Higher education in the learning society. U.K, 97BBC Politics 97. Retrieved from http://ww.hi.is/ joner/eaps/dearing2.htm

Ebewo, P. E., \& Shambare, R. (2012). The reason business plans of start-up ventures are rejected by South African financiers: Evidence from SIFE-TUT Harmony Fashion Design Business Challenge. Emerging Markets Conference of the International Management Research Academy (IMRA), London, 17-18 May 2012, IMRA.

Gallaway, L., Andersson, M., Brown, W., \& Whittam, G. (2005). The Impact of Entrepreneurship Education in Higher Education. Report for Business Education support team, School of Management and Languages, Heriot-watt university, Edinburgh.

Hossan, C., Parankandi, M., \& Saber, H. (2013). An Empirical Study on the UAE Business Student's Entrepreneurial Knowledge, Preferences and Perceived Barriers. UAE.

Kolvereid, L. (1996). Prediction of employment status choice. Management Journal, 1(2), 165-182.

Kolvereid, L., \& Moen, Ø. (1997). Entrepreneurship among business graduates: Does a major 
in entrepreneurship make a difference? Journal of European Industrial Training, 21(4), 154-160. http://dx.doi.org/10.1108/03090599710171404

Kumar, R. (2005). Research methodology: A-step-by-step Guide for Beginners (2nd ed.). Singapore: Pearson Education.

Lazear, E. (2003). Entrepreneurship. IZA, Discussion Paper, (760), April 2003.

Makgosa, R., \& Ongori, H. (2012). Perceptions of Entrepreneurial Behaviour in Botswana. International Journal of Learning \& Development, 2(3), 247-259. http://dx.doi.org/10.5296/ijld.v2i3.1885

McMullan, W. E., \& Gillin, L. M. (1998). Developing technological start-up entrepreneurs: A case study of a graduate entrepreneurship programme at Swinburne University. Technovation, 18(4), 275-286. http://dx.doi.org/10.1016/S0166-4972(97)00119-3

Muthalib, A. A., \& Yulianti, M. N. (2015). The Effect of Entrepreneur Motivation on Business Performance in the Culinary Industrial Sector. Journal of Engineering and Sciences, 4(7), 23-30.

Nabi, G., \& Holden, R. (2008). Graduate Entrepreneurship: Intentions, Education and Training. Journal of Education + Training, 50(7), 545-551. http://dx.doi.org/10.1108/00400910810909018

Pajarinen, M., Rouvinen, P., \& Yla“-Anttila, P. (2006). Ministry of Employment and the Economy, Helsinki.

Roberts, R. (2004). Current and Future Trends in Graduate Enterprise- A Banking Perspective. ACCA Seminar June.

Rushing, F. W. (1990). Entrepreneurship and education In C. A. Kent (Ed.), Entrepreneurship Education: Current Developments, Future Directions (pp. 29-40). Westport, CT: Quarum Books.

Schoof, U. (2006). Stimulating youth entrepreneurship: barriers and incentives to enterprise Start-ups by young people, SEED Working Paper No. 76. Small, Small enterprise Development programme job creation and enterprise development department, International labour office Geneva, Switzerland, pp. 1-37.

Schumpeter, J. A. (1949). The Theory of Economic Development. U.K.: Harvard University Press.

Shinnar, R., Pruett, M., \& Toney, B. (2009). Entrepreneurship education: Attitudes across campus. Journal of Education for Business, 84(3), 151-159. http://dx.doi.org/10.3200/JOEB.84.3.151-159

Talaş, E., Çelik, A. K., \& Oral, O. I. (2013). The influence of demographic factors on entrepreneurial intention among undergraduate students as a career choice: The case of Turkey University. American International Journal of Contemporary Research, (12). http://dx.doi.org/10.2139/ssrn.2497310 


\section{Macrothink}

Global Journal of Educational Studies

ISSN 2377-3936 2016, Vol. 2, No. 2

Tanveer, A. M., Gillani, A. U., Rizvi, S., \& Latif, M. (2010). Barriers for business students in becoming an Entrepreneur in Pakistan. Journal of Business and Management, 24(4), 74-82.

Van der Walt, R., \& Van der Walt, S. J. (2008). Entrepreneurial Training for Human Resource Practitioners and Potential Services rendered to Small Enterprises. South African Journal of Entrepreneurship and Small Business Management, 1, 21-34. http://dx.doi.org/10.4102/sajesbm.v1i1.12

Wong, M., \& Choo, S. (2006). Entrepreneurial intention: Triggers and barriers to new venture creations in Singapore. Singapore Management Review, 28(2), 47-64.

World Economic Forum. (2009). World Economic Forum Unlocking Entrepreneurial Capabilities to Meet the Global Challenges of the 21st Century - A Report of the Global Education Initiative. Educating the Next Wave of Entrepreneurs, April 2009.

\section{Copyright Disclaimer}

Copyright for this article is retained by the author(s), with first publication rights granted to the journal.

This is an open-access article distributed under the terms and conditions of the Creative Commons Attribution license (http://creativecommons.org/licenses/by/3.0/). 